\title{
Thermal event records in SE China coastal areas: Constraints from Monazite Ages of Beach Sands from two sides of the Taiwan Strait
}

\author{
Cheng-Hong Chen ${ }^{\mathrm{a}, *}$, Hsueh-Yu Lu $^{\mathrm{b}}$, Wayne Lin ${ }^{\mathrm{c}}$, Chi-Yu Lee ${ }^{\mathrm{a}}$ \\ a Department of Geosciences, National Taiwan University, Taipei 10699, Taiwan \\ b Department of Earth Sciences, National Chung-Cheng University, Chiayi, Taiwan \\ ${ }^{\mathrm{c}}$ Energy and Environment Research Laboratories, Industrial Technology Research Institute, Hsinchu 310, Taiwan
}

Received 29 March 2005; received in revised form 30 December 2005; accepted 13 January 2006

\begin{abstract}
CHIME ages of $>460$ detrital monazites from beach sands from SE China (Chinmen Island) and W Taiwan were determined in order to deduce the major tectonothermal events affecting the coastal areas of SE China. Additional 360 monazites from estuarine sediments of the Minjiang River (eastern China), metamorphic rocks from Chinmen Island and sedimentary rocks from W Taiwan were also dated. Ages of the Chinmen beach monazites (245-80Ma) reveal that they are derived from adjacent gneisses and mixed with sediment from the Jiulongjiang River (SE China). Some large, euhedral monazites contain older cores ( 220 Ma) and younger rims (137-124Ma), demonstrating that overgrowth on inherited Indosinian grains occurred at the time of gneiss formation (137 Ma). Monazites of W Taiwan fall into two age groups, one in the Paleoproterozoic (1900-1650Ma) and the other spanning the Phanerozoic (530-120 Ma). Based on similar ages of Phanerozoic monazites from the Minjiang River and W Taiwan, monazites of the latter group are inferred to be derived mainly from this river, hence the Paleoproterozoic monazites are most probably derived from Cathaysia basement exposed in the drainage basin of the Wuyishan (NW Fujian). Along with monazite ages of the two-mica schist, sediments from the uplifted Changle-Nanao shear zone (CNSZ) constitute only a minor component of deposits in W Taiwan. The age frequency distribution of Phanerozoic monazites from W Taiwan, which shows peaks at 450-430, 360-350, $\sim 275$ and $\sim 245$ Ma suggests the existence of Caledonian, Hercynian and Indosinian crust beneath the immense Yanshanian cover of the SE China coastal area.
\end{abstract}

(C) 2006 Elsevier B.V. All rights reserved.

Keywords: CHIME monazite age; Cathaysia Block; SE China; W Taiwan

\section{Introduction}

Precise dating of igneous and metamorphic rocks has long been the target for geologists to unravel the nature of thermal events on earth. The $\mathrm{U}-\mathrm{Pb}$ zircon and

\footnotetext{
* Corresponding author. Mailing address: Department of Geosciences, National Taiwan University, No. 1, Roosevelt Road Section 4, Taipei 10699, Taiwan. Tel.: +88623366 5872; fax: +886223636095.

E-mail address: chench@ntu.edu.tw (C.-H. Chen).
}

monazite isotopic ages are by far the most widely adopted method to constrain the time of magma emplacement or high-grade metamorphism. A less precise but more easily accessible dating technique, the chemical Th-U-total Pb isochron method (CHIME), has been applied by using a more common device-the electron microprobe (e.g., Suzuki and Adachi, 1994). Due to its high concentration of Th and $U$ and low common $\mathrm{Pb}$ contents, monazite is ideal for such geochronology (e.g., Parrish, 1990; Montel et al., 
1996; Cocherie et al., 2005). Generally speaking, CHIME monazite method is capable of dating rocks older than $100 \mathrm{Ma}$ (Rhede et al., 1996), and may be applied to younger ( $\sim 80 \mathrm{Ma})$ rocks as well (Suzuki et al., 1996; Tsuboi and Suzuki, 2003).

The SE China coastal area is basically a terrain consisting of the Late Mesozoic intrusive and volcanic rocks on the eastern margin of the South China continent. Since the beginning of the Cenozoic, evolution of the continental slope off SE China, now the Taiwan Strait and Taiwan island, involved two major stages of rifting associated with subsidence in the Eocene-Oligocene and Miocene, respectively, that resulted in a thick sequence $(>10 \mathrm{~km})$ in rifted basins (Lin and Watts, 2002). Ages of detrital minerals in large river systems have been demonstrated to be able to provide important information about regional tectonothermal events and erosion-deposition relation (e.g., Indochina; Bodet and Scharer, 2000). Beach placers on the coast of $\mathrm{W}$ Taiwan contain abundant black and yellow monazites (Overstreet, 1971). Aside from the black variety that is suggested to be authigenic in origin (Matzko and Overstreet, 1977), CHIME monazite ages (hereafter referred to as monazite ages) of the yellow variety are able to shed the light for the source to sink relation of these recycled sediments.

The purpose of this study is to know the main phases of thermal event of the SE China coastal area revealed from the monazite ages of beach sediments in W Taiwan. To constrain the contribution of possible supplying components, estuarine sediments of the most potential river system as well as the beach sands and metamorphic rocks of the SE China coastal area and one sedimentary rock in W Taiwan are examined in a similar way. With the insight of these ages, the provenance of sediments in W Taiwan, which has long been a debate (Bien, 1971; Chen et al., 1990, 2000), are also evaluated.

\section{Geological background}

The South China Block is one of the old cratons of the east Eurasia continent, surrounded by the North China Block in the north, the Songpan Ganzi terrain in the west and the Indochina Block in the southwest (Fig. 1). It is subdivided into the Yangtze Block and the Cathaysia Block that amalgamated in the Neoproterozoic (Li et al.,

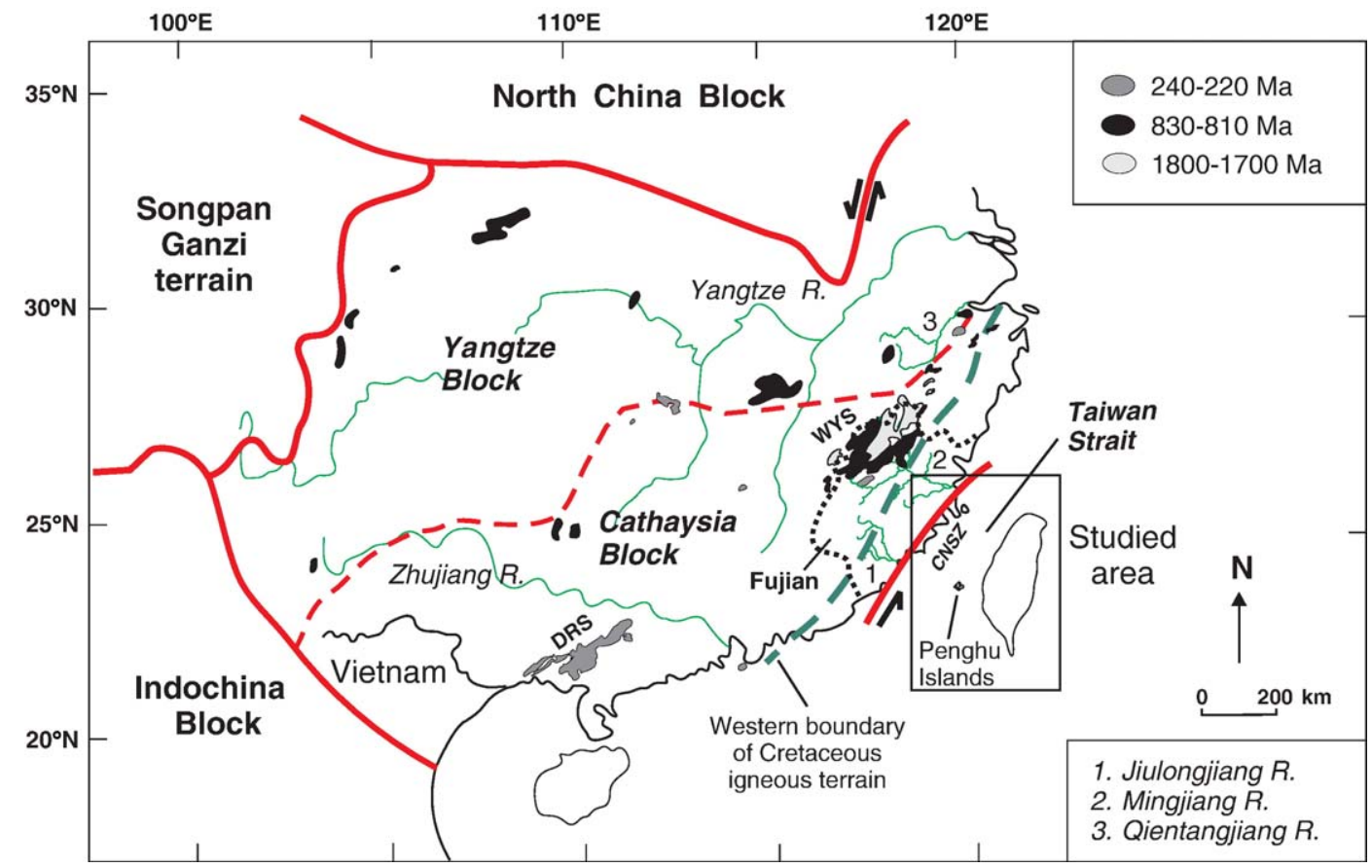

Fig. 1. Position of the Taiwan Strait relative to the Cathaysia Block, including distributions of the Paleoproterozoic (1800-1700 Ma), Late Jinning (830-810 Ma) and Indosinian ( 220Ma) granitoids, and drainage systems of the Yangtze, Qientangjiang, Mingjiang and Jiulongjiang Rivers. The light dashed line is the boundary of the Yangtze and Cathaysia Blocks and the heavy dashed line is the boundary of the Cretaceous and Jurassic igneous terrains in the Cathaysia Block. WYS and DRS denote the Wuyishan and Darongshan areas, and CNSZ, the Changle-Nanao shear zone. Note that the Mingjiang River system originates at the Wuyishan. 
2003). The age of the Cathaysia basement is considered as Paleoproterozoic (e.g., Chen and Jahn, 1998), evidenced by the well-known exposures in Wuyishan, NW Fujian. This block has been subjected to various stages of granitic intrusions ( \pm metamorphism) during the Neoproterozoic and Early Phanerozoic (Shen and Lin, 2002).

Principal Phanerozoic orogenies in the South China Block have been broadly related to the Caledonian, Hercynian, Indosinian (Triassic) and Yanshanian thermal events (Chen and Jahn, 1998). So far, only temporal and spatial variations of Yanshanian magmatic activities are better understood: Early Yanshanian (EY; Jurassic) rocks occur in large parts of the Cathaysia Block and Late Yanshanian (LY; Cretaceous) rocks cover the SE China coastal area (Fig. 1). Further southeast is a narrow belt of the ChangleNanao shear zone (CNSZ), or the LY metamorphic core complex composed mainly of gneissic, migmatitic and granitic rocks dated about $140-110 \mathrm{Ma}$ (Chen et al., 2004). There are also metasedimentary rocks with unknown ages, which have been regarded as the country rocks for these intrusives (Chen et al., 2002).
The influence of Early Phanerozoic orogenesis in the SE China coastal area is obscure because its surface is heavily covered by EY and LY granitoids. Major rivers running on the Cathaysia Block like Yangtze, Minjiang and Jiulongjiang, may be able to bring washouts of the underlain rocks to reside in their river mouths and further deposit in the subsided continental margin. Situated in the river channel of the paleo-Jiulongjiang River, Chinmen was deposited with Oligocene-Miocene sediments of this river known as the Chinmen Formation. Also situated in the middle of the CNSZ (Fig. 2), Chinmen is an ideal place for revealing the ages of different components in this zone.

The island of Taiwan was formed by thickening of the crust in the continental slope due to the collision between the Eurasian and the Philippine Sea plate since the Late Miocene (Teng and Lin, 2004). Sedimentary sequences of $\mathrm{W}$ Taiwan, mainly alternating sandstones and shale, are distributed with the $\mathrm{N}-\mathrm{S}$ trending Neogene strata in the foothills and Paleogene strata in the Central Range (Fig. 2a). Because of the drainage patterns in W Taiwan, beach sands in the northwest are mostly derived from the Neogene, whereas those in the

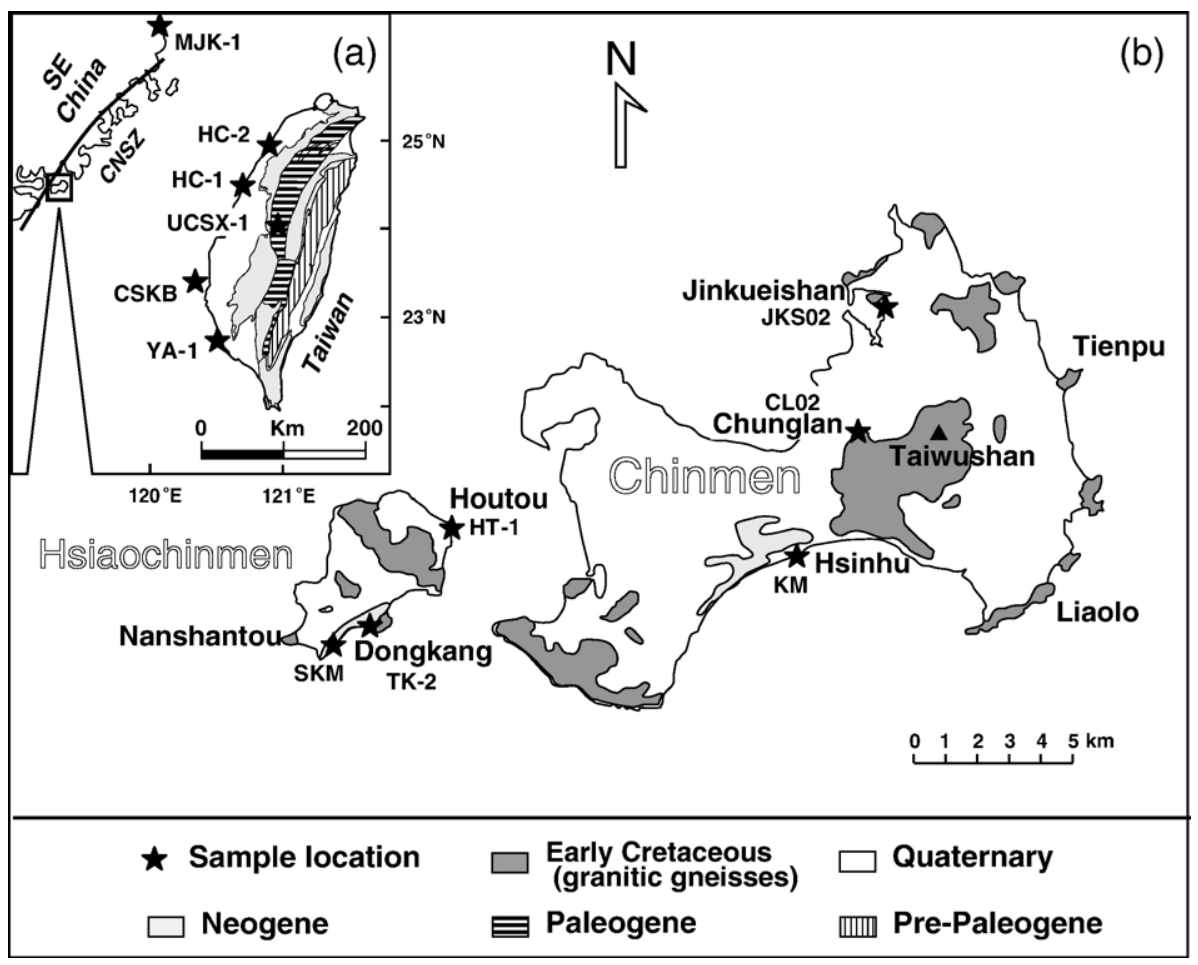

Fig. 2. Simplified geological maps of the studied area (Fig. 1) with sample localities: (a) Miaoli (HC-1), Hsinchu (HC-2), Chiayi (CSKB), Tainan (YA-1) and the Paleogene strata (UCSX-1) in W Taiwan, and Minjiang River mouth (MJK-1) in E Fujian; (b) Hsinhu (KM) in Chinmen, and Nanshantou (SKM), Houtou (HT-1) and Dongkang (TK-2) in Hsiaochinmen. Moreover, the Chunglan gneiss (CL02) and Jinkueishan two-mica schist (JKS02) are also included. The Neogene in the Chinmen area is the Chinmen Formation, and beach sands from KM and SKM are designated to know the influence of this formation. 
southwest from both the Paleogene and Neogene strata (Chen et al., 2000).

Phanerozoic thermal events were suggested to have involved either metamorphism of the Proterozoic basement (the Caledonian metamorphic belt; Shen and Lin, 2002) or extensive remelting of crustal materials (the Indosinian and EY overprints; Xu et al., 2005). Therefore, rocks related to these events are potential sources for generating monazites (Parrish, 1990). On this basis, the monazite age spectra of the sediments contributed from the SE China coastal area in the Cenozoic depositional cycle can be used for tracing Phanerozoic thermal events.

\section{Sample preparation}

Samples were collected from four localities in the Chinmen area (HT-1, TK-2, SKM, and KM) and five in W Taiwan (HC-1, HC-2, CSKB, YA-1 and UCSX-1). In addition, river mouth sediments of Minjiang (MJK-1) were also included. For better constraining various sources of monazite, two rock samples in Chinmen, including the gneiss at Chunglan (CL02) and the twomica schist at Jinkueishan (JKS02), were crushed for collecting monazites (Fig. 2b). In sample CL02, we found that the coexisting cheralite, the $\mathrm{Ca}$ - and Th-rich variety of the monazite group or $(\mathrm{Ce}, \mathrm{Ca}, \mathrm{Th})(\mathrm{P}, \mathrm{Si}) \mathrm{O} 4$, is able to provide CHIME ages as well.

Samples $(5-50 \mathrm{~kg})$ were cleaned and subjected to magnetic removal of magnetite, and then run through a rocking table for collecting the heaviest portion. From these heavy sands, monazites (generally occupying 1-2 vol.\%) were either hand-picked under the stereo microscope or gravitationally separated with a heavy liquid. It is noted that monazites of samples KM, SKM, HC-1 and CSKB are taken from concentrates for mining purpose, and thus represent mixtures covering a large sampling area up to several $\mathrm{km}^{2}$ rather than one small site like others.

Monazite generally forms rounded grains in the beach sands except at Houtou (HT-1) where it keeps prismatic outlines and even double pyramids $(500 \times 400 \mu \mathrm{m})$. Oval shapes with long axis in $\sim 400 \mu \mathrm{m}$ and short axis in $\sim 300 \mu \mathrm{m}$ are common for TK-2 and SKM, and smaller sizes for others: $\sim 200 \times 100 \mu \mathrm{m}$ (KM and HC-1), $100 \times 80 \mu \mathrm{m}(\mathrm{HC}-2$ and UCSX-1), $80 \times 60 \mu \mathrm{m}(\mathrm{CSKB}$, YA-1 and CL02) and $~ 50 \mu \mathrm{m}$ (JKS02). We mainly focus on dating the core ages to reveal the main populations of the presumed formation time for these monazites. A simple reconnaissance on the age difference between the core and rim is carried out for some large euhedral monazites $(>350 \mu \mathrm{m})$.

\section{Analytical methods}

The instrument used is a Shimadzu-ARL electron microprobe model EMX-SM equipped with 4 channels of wavelength-dispersive spectrometers. The acceleration potential of $15 \mathrm{kV}$, sample current of $20 \mathrm{nA}$ and smaller beam size of $\sim 5 \mu \mathrm{m}$ is adopted to allow a better spatial resolution (Montel et al., 1996; Crowley and Ghent, 1999). Epoxy-mounted monazites are measured for $\mathrm{Th}, \mathrm{U}, \mathrm{Pb}$ and $\mathrm{Y}$ contents simultaneously, and standards are synthetic $\mathrm{ThO}_{2}, \mathrm{UO}_{2}, \mathrm{PbS}$ and $\mathrm{YAG}(\mathrm{Y}-$ Al-garnet with $\left.\mathrm{Y}_{2} \mathrm{O}_{3}=57.1 \mathrm{wt} . \%\right)$. These standards are basically similar to those described by Cocherie and Albarede (2001). Counting times are total $180 \mathrm{~s}(3 \times 60 \mathrm{~s})$ on characteristic X-ray lines and $360 \mathrm{~s}(6 \times 60 \mathrm{~s})$ on backgrounds.

X-ray lines adopted are $M_{\alpha}$ for Th and $\mathrm{Pb}$, and $M_{\beta}$ for $\mathrm{U}$ and $L_{\alpha}$ for $\mathrm{Y}$ to avoid interferences of $\mathrm{Th} M_{\beta}$ on $\mathrm{U} M_{\alpha}$ and crystals used are ADP and PET. Correction for the interference of YLã on $\mathrm{Pb} M_{\alpha}$ is made on the YAG standard as well. Moreover, the data reduction for ZAF corrections (Chen and Tung, 1984) is based on fixed weight mode of $\mathrm{P}$ and REE (Pyle et al., 2005). With our apparatus, detection limits of $\mathrm{PbO}$ and $\mathrm{UO}_{2}$ at $1 \sigma$ confidence level are 0.018 and $0.016 \mathrm{wt} . \%$, respectively, and the relative error is $12 \%$ in $\mathrm{Pb}$ and $\mathrm{U}$. A systematic error of $2 \%$ is considered for $\mathrm{ThO}_{2}$, and also for $\mathrm{PbO}$ and $\mathrm{UO}_{2}$, above 1 wt. $\%$.

Apparent ages calculated from the analysis for all the studied monazite grains are listed in Appendix A (available on the web). Single grain analysis and discrete grains of monazite that define a significant linear trend in the $\mathrm{PbO}$ versus $\mathrm{ThO}_{2}^{*}\left(\mathrm{ThO}_{2}\right.$ incorporating $\mathrm{UO}_{2}$ equivalents) plot are used to calculate an age isochron and the mean square of weighted deviates (MSWD) by adopting the best fitting slope of linear regression model (Kato et al., 1999). Although no common $\mathrm{Pb}$ correction has been considered (Cocherie et al., 2005), the isochron thus obtained can also provide a simple assessment for the common $\mathrm{Pb}$ effect on cogenetic detrital grains (Suzuki and Adachi, 1998). For the total age population of beach sand monazites in certain areas, the ISOPLOT3 program (Ludwig, 2003) is used to construct the age frequency curve. Test of the methodology for present analytical conditions is made by determining monazite ages in a medium-grained, almandine- and cordieritebearing granite of the Darongshan Complex, S China (Fig. 1). The isochron age obtained $(224 \pm 13 \mathrm{Ma}$ based on 17 grains, Fig. 3a) is in agreement with the in situ monazite age $(213 \pm 23 \mathrm{Ma}$ on 14 measurements, Montel et al., 1996) and the SHRIMP U-Pb zircon 


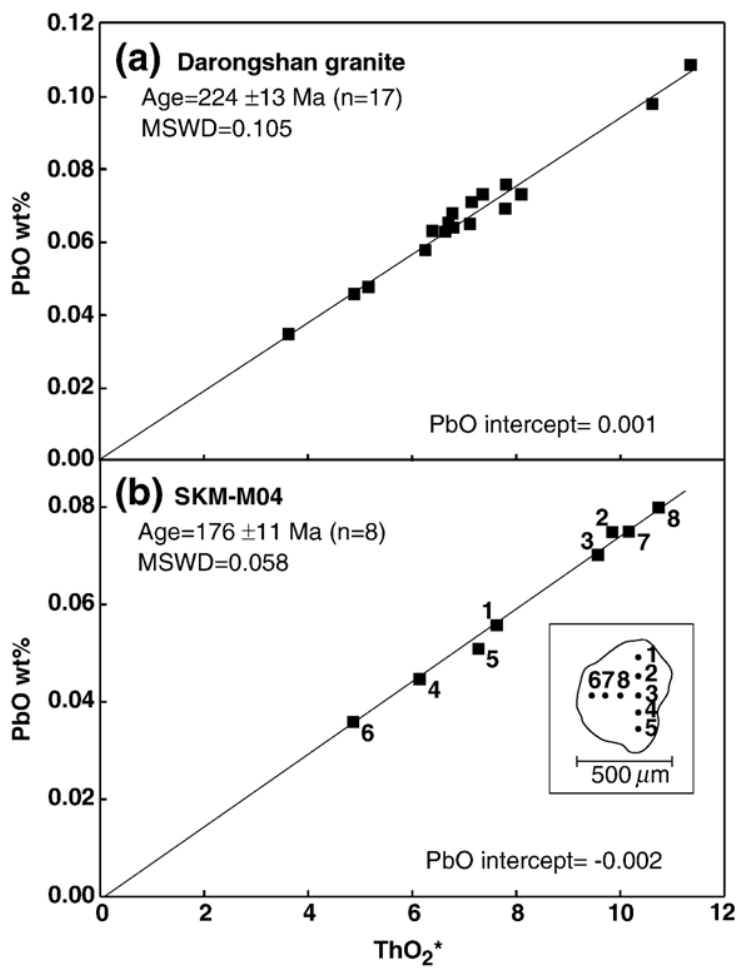

Fig. 3. $\mathrm{PbO}$ vs. ThO 2 plots for revealing monazite age isochrons of (a) the Darongshan granite, S Guanxi (for self-test of the methodology), and (b) a single-grain spot analysis (SKM-M04 from Hsiaochinmen). Ages and uncertainties $(2 \sigma)$ are calculated using the method of Kato et al. (1999). The latter case shows the consistency of apparent ages despite a large variation of $\mathrm{ThO}_{2}$ and $\mathrm{PbO}$ contents in this monazite (Appendix).

age $(230 \pm 4 \mathrm{Ma}$ on 13 measurements, Deng et al., 2004).

\section{Results}

\subsection{Ages of Chinmen monazites}

The great majority of beach sands monazites exhibit a small range of apparent ages irrespective of the $\mathrm{ThO}_{2}, \mathrm{UO}_{2}$ and $\mathrm{PbO}$ variations in the grain. This can be exemplified by the result of a large subrounded monazite grain SKM-M04 that yields an isochron age of $176 \pm 11 \mathrm{Ma}$ based on 8 spot analyses (Fig. 3b). However, multi-stage development of monazites has been observed for large euhedral grains. In sample HT1, rims of euhedral grains generally yield younger apparent ages, by which an isochron age of $124 \pm 8 \mathrm{Ma}$ can be calculated when incorporated with ages of the youngest group of monazites. On the other hand, their cores and other monazites display two older ages of $159 \pm 8$ and $219 \pm 12 \mathrm{Ma}$ (Fig. 4a). Similarly, two groups of age can be distinguished in sample TK-2: a large number of monazites result in a younger isochron age of $137 \pm 5 \mathrm{Ma}$, and the rest yields an older isochron age of $223 \pm 27 \mathrm{Ma}$ (Fig. 4b). A monazite core age of $\sim 220 \mathrm{Ma}$ seems to be a common feature for samples HT-1 and TK-2.

Apparent ages of monazites in sample SKM $(n=107)$ basically fall in the Mesozoic ranging from 245 to $80 \mathrm{Ma}$ $(n=98)$, with few in the Paleoproterozoic $(\sim 1860 \mathrm{Ma}$, $n=1)$ and Paleozoic (470-265Ma, $n=8$ ) (Fig. 4c). Among the Mesozoic monazites, the age groups of 146-121 Ma $(n=23)$ and 90-80 Ma $(n=16)$ coincide well with the time of gneiss formation and rhyolite eruptions, respectively, in the SE China coastal area (Chen et al., 2004). Others reveal a continuous age spectrum in the Early Mesozoic. The scarcity of 120 $90 \mathrm{Ma}$ monazites is due to the large exposure of monazite-free I-type hornblende-bearing granites in the studied area that emplaced at this time. Monazites of sample KM, with an age span of $215-83 \mathrm{Ma}(n=20)$, are similar to the essential group obtained from sample SKM. More than half of the data set $(n=11)$ can reveal a significant isochron age of $139 \pm 5 \mathrm{Ma}$ (Fig. $4 \mathrm{~d}$ ), reflecting the influence of adjacent gneissic body (Taiwushan; Fig. 2b; see later section).

Apparent ages obtained from monazites in the Chunglan gneiss (CL02) can be divided into two groups: the older group of $485-208 \mathrm{Ma}(n=16)$ and the younger group of $144-133 \mathrm{Ma}(n=17)$. Most monazites in the older group are confined to a narrow time span (234$212 \mathrm{Ma}, n=10)$ leading to an isochron age of $223 \pm 23 \mathrm{Ma}$ (Fig. 4e). Cheralites $\left(\mathrm{ThO}_{2}=36.8-48.5 \mathrm{wt} . \%, \mathrm{UO}_{2}=2.3-\right.$ 7.4 wt. $\%$ and $\mathrm{PbO}=0.26-0.39$ wt.\% on 17 grains) show a small range of apparent ages from 143 to $132 \mathrm{Ma}$. By combining cheralites and the younger group of monazites based on the similarity of age ranges, an isochron age of $137 \pm 5 \mathrm{Ma}$ is obtained (Fig. 4e), which is in good accord with the U-Pb zircon age of the Taiwushan gneiss (139.4 $\pm 0.4 \mathrm{Ma}$; Yui et al., 1996) - the same unit as the Chunglan gneiss (Fig. 2b). Coexistence of the 223 and $137 \mathrm{Ma}$ monazites in Chunglan gneiss coincides very well with the case of beach sands in sample TK-2 that shows two groups of monazite ages: 221 and $137 \mathrm{Ma}$ (Fig. 4b). This indicates that the beach sand monazites here are basically derivatives of a gneissic body equivalent to Chunglan or Taiwushan.

Monazites in the Jinkueishan two-mica schist (JKS02) are mostly the Paleozoic and Mesozoic ages (Fig. 4f). Except one Paleoproterozoic age (1797 Ma) preserving in the core of a grain with the rim age of $385 \mathrm{Ma}$, there is no other Precambrian age among 70 analyses. Without counting the particularly old grain of 

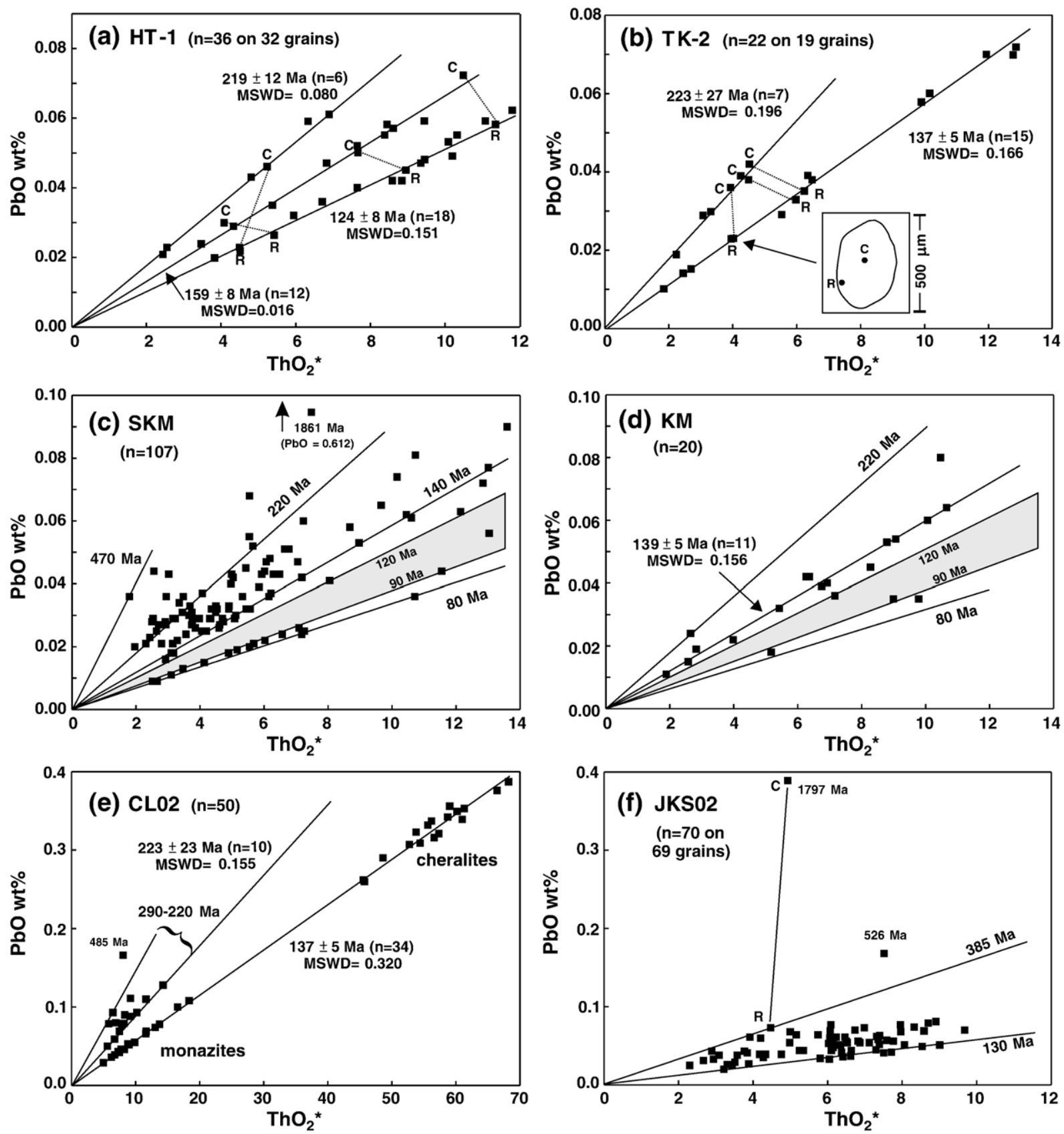

Fig. 4. PbO vs. ThO ${ }_{2}^{*}$ plots for monazites from (a) Houtou (HT-1), (b) Dongkang (TK-2) and (c) Nanshantou (SKM) in Hsiaochinmen, (d) Hsinhu (KM), (e) Chunglan (CL02), and (f) Jinkueishan (JKS02) in Chinmen (Fig. 2b). Samples HT-1 and TK-2 contain many large euhedral monazites and the tie lines connect core (C) and rim (R) compositions. Lack of ages pertaining to the range of 120-90 Ma (shaded in SKM and KM) is noted (see text for explanation). Few isochrons (with uncertainties) are constructed for representing the age of monazite hosts or adjacent igneous bodies; and age reference lines (without uncertainties) are shown for comparison.

$526 \mathrm{Ma}$, Paleozoic ages spread between 385 and $250 \mathrm{Ma}$ $(n=19)$ and Mesozoic ages are nearly a continuous spectrum ranging from 234 to $129 \mathrm{Ma}(n=49)$. These results provide a maximum age for the sediment deposition of $\sim 130 \mathrm{Ma}$.
5.2. Ages of the river mouth monazites from Minjiang $(M J K-1)$

River mouth sediments here represent samples unaffected by the major LY shear movement in the 

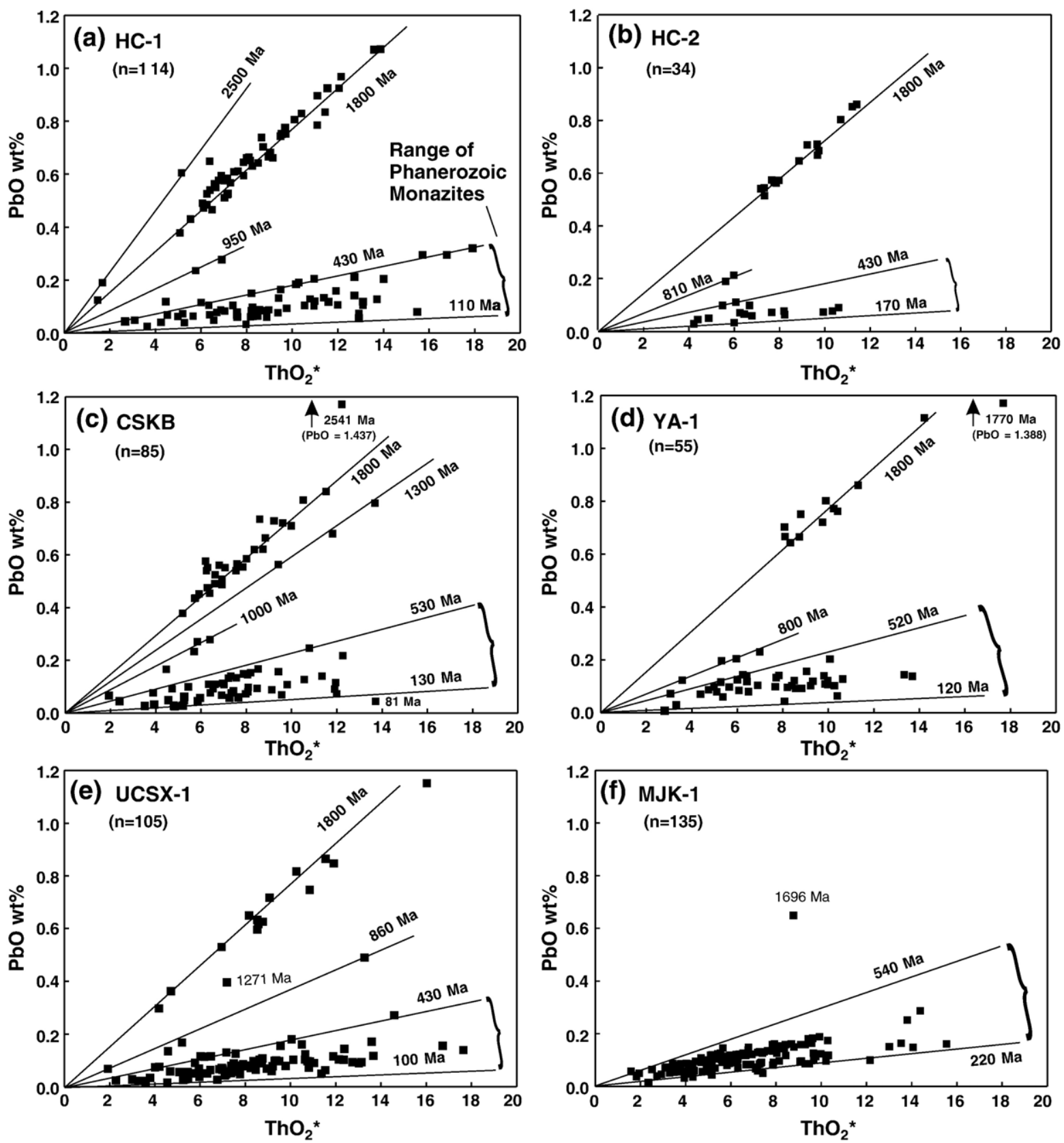

Fig. 5. PbO vs. ThO 2 plots for monazites from (a) Miaoli (HC-1), (b) Hsinchu (HC-2), (c) Chiayi (CSKB), (d) Tainan (YA-1) and (e) the Paleogene strata (UCSX-1) in W Taiwan, and (f) Minjiang River mouth (MJK-1) in E Fujian (Fig. 2a). Only age reference lines are shown.

coastal area as sampling sites are west to the CNSZ. Monazites in sample MJK-1 are mostly angular to subangular and large in grain size $(200-300 \mu \mathrm{m})$, indicative of short distance of transportation. The great majority falls in the range between 540 and $220 \mathrm{Ma}(n=109$ out of 135 ; Fig. $5 \mathrm{f}$ ) despite that the sampling site is close to a large Cretaceous igneous terrain (Fig. 1). Major age groups are $540-510 \mathrm{Ma}$ $(n=13), 480-405 \mathrm{Ma}(n=55), 380-330 \mathrm{Ma}(n=22)$, 295-270 Ma $(n=17)$ and 250-220Ma $(n=12)$. The most significant group of $480-405 \mathrm{Ma}$ matches the Caledonian thermal event of $470-425 \mathrm{Ma}$ in the Cathaysia interior (Xu et al., 2005). Precambrian populations are rather small, containing only few ages of $1700 \mathrm{Ma}(n=1), \sim 840 \mathrm{Ma}(n=1)$ and $610-600 \mathrm{Ma}$ $(n=3)$. 


\subsection{Ages of $W$ Taiwan monazites}

Miaoli and Hsinchu (HC-1 and HC-2) and Chiayi and Tainan (CSKB and YA-1) areas in the NW and SW Taiwan, respectively, are designated for distinguishing monazites preserved in the Neogene and Paleogene sedimentary rocks. In addition, sample UCSX-1 is used to constrain monazites derived from the Paleogene strata in W Taiwan. Overall monazite ages obtained from sample HC-1 are of two main groups: one can be regarded as pertaining to a cluster of $\sim 1800 \mathrm{Ma}$, and the other spreads between 430 and $110 \mathrm{Ma}$ (Fig. 5a). Sample HC-2 displays coherent age patterns with an age population of $\sim 1800 \mathrm{Ma}$ and random distributions of data spreading between 430 and $170 \mathrm{Ma}$ (Fig. 5b). Consistency of age patterns from these two samples reflects the generality of same monazite sources. Altogether $(n=148)$, ages beyond these two main groups, i.e., $\sim 1800$ and $430-110 \mathrm{Ma}$, are very few and present at $2600-2300 \mathrm{Ma}(n=3), 950-790 \mathrm{Ma}(n=4)$, and $\sim 620 \mathrm{Ma}(n=1)$.

For samples of SW Taiwan (CSKB and YA-1), again, two monazite age clusters are observed: an older group of $\sim 1800 \mathrm{Ma}$ and a younger group spreading between 530 and $130 \mathrm{Ma}$ (Fig. 5c) or 520-120 Ma (Fig. 5d). Put together all these data $(n=140)$, other ages include $\sim 2500 \mathrm{Ma} \quad(n=1)$, $\sim 2000 \mathrm{Ma}(n=6), \sim 1300 \mathrm{Ma} \quad(n=3)$ and $1100-$ $800 \mathrm{Ma}(n=9)$. As compared with the Miaoli-Hsinchu samples, the age of $530-510 \mathrm{Ma}$ is characteristic and contributions of the Neoproterozoic monazites seem to be more abundant in these two samples. Moreover, monazite ages of sample UCSX-1 $(n=105)$ mostly belong to the Phanerozoic (430-84Ma) and the rest to the Proterozoic, including $1800-1600 \mathrm{Ma}(n=14)$, $\sim 1300 \mathrm{Ma}(n=1)$, and $900-700 \mathrm{Ma}(n=3)$ (Fig. 5e). The relative proportion of the Paleoproterozoic monazites is significantly smaller than the beach sand samples.

\section{Discussion}

\subsection{Applicability of monazite ages}

In the application of CHIME geochronology for metamorphic rocks, the age and zoning pattern of cores are sometimes different from grain to grain even within a rock sample when older cores are mantled by younger rims (Suzuki and Adachi, 1994; Cocherie et al., 1998; Crowley and Ghent, 1999; Williams and Jercinovic, 2002). It has been suggested that $\mathrm{Pb}$ diffusion loss from monazites is generally insignificant for metamorphism of upper amphibolite facies or even granulite facies up to $900{ }^{\circ} \mathrm{C}$ if no fluid is involved (Braun et al., 1998; Montel et al., 2000; Cherniak et al., 2004). Hence, core monazite ages can retain the record of pre-metamorphic thermal events. On the other hand, new monazites may be generated from the breakdown of REE-bearing minerals during high $T /$ low $P$ amphibolite facies (e.g., Dunning et al., 1995; Cherniak et al., 2004) or high $T / P$ granulite facies metamorphism (e.g., Bingen et al., 1996).

\subsection{Thermal records reflected by gneisses}

The younger isochron ages of $124 \pm 8 \mathrm{Ma}$ (HT-1), $137 \pm 5 \mathrm{Ma}$ (TK-2) and $139 \pm 5 \mathrm{Ma}$ (KM) obtained from detrital samples in the Chinmen area (Fig. 4a, b and d) can be related to the main-phase thermal event for the formation of gneisses in the CNSZ (Chen et al., 2004). This is supported by the younger isochron age of $137 \pm 5 \mathrm{Ma}$ shown in the gneissic rock sample CL02 (Fig. 4e). Therefore, one important source for Chinmen monazites is the gneissic rock. In dealing with the tectonic evolution in SE China, Jahn et al. (1976) and Yui et al. (1996) have drawn attentions for the age of $\sim 160 \mathrm{Ma}$ in Chinmen rocks as a stage of large-scale anatexis. In fact, inherited zircons of $\sim 160 \mathrm{Ma}$ are commonly present in many gneissic bodies in Chinmen (our unpublished data). However, the thought that precedent rocks for gneisses are the EY magmatic product before metamorphism (Chen et al., 2004) can only be reflected by a loosely defined monazite core age of $159 \pm 8 \mathrm{Ma}$ in sample HT-1 (Fig. 4a).

Tectonothermal events pertaining to the Indosinian orogeny has rarely been mentioned in the SE China coastal area, thus, the presence of $\sim 220 \mathrm{Ma}$ monazite grain and core ages in Chinmen samples appears to be a new finding. Monazites of sample CL02 provide useful information: in addition to the well-defined metamorphism age of $137 \mathrm{Ma}$, there exists another isochron age of $223 \mathrm{Ma}$ and a group of older age ranging from 485 to $256 \mathrm{Ma}$ (Fig. 4e). Monazites older than $\sim 220 \mathrm{Ma}$ are explained as xenocrysts due to wall rock contamination and/or inherited grains derived from older rocks at the site of melt generation. Dominance of $\sim 220 \mathrm{Ma}$ monazites in this group, along with the common existence of monazites with same ages in beach sands, favors the origin of Paleozoic contaminants during ascend of magmas plus residues after remelting of Indosinian crusts. Such crusts have endured extensive LY $( \pm \mathrm{EY})$ overprints with thermal conditions lower than the $\mathrm{Pb}$ closure temperature $\left(>900^{\circ} \mathrm{C}\right)$ allowing inherited 
monazites to survive (Cherniak et al., 2004; SeydouxGuillaume et al., 2002).

\subsection{Metasedimentary rocks and sediment sources of} Chinmen samples

The CNSZ was active during the Late Mesozoic. Using amphibole geobarometry, granitic gneisses in this zone were suggested to have emplaced at depths of 18 $24 \mathrm{~km}$ (Chen et al., 2004). Because metasedimentary rocks have been found in direct contact with gneissic rocks in few localities of the CNSZ and the maximum age of sediment deposition is $\sim 130 \mathrm{Ma}$ (Fig. $4 \mathrm{f}$ ), they should have deposited in this shear zone at the expose of gneissic rocks (110 Ma; Yang et al., 1997). This rules out the possibility that they represent the Paleozoic sedi- mentary wall rocks of these gneisses (Chen et al., 2002). The lack of monazites of $90-80 \mathrm{Ma}$ is a sign that deposition of sediments ended before onset of anorogenic rhyolitic volcanism. Therefore, the post-orogenic subsidence in the CNSZ can be confined in a time span of 110-90 Ma to receive large volumes of such sediments. Probably until Early Cenozoic (the time of major stratigraphic hiatus in Taiwan Strait), the CNSZ was tectonically uplifted again.

The age spectrum of these metasediments ( $\mathrm{JKS} 02)$ shows the highest peak at $195 \mathrm{Ma}$ and two moderate peaks at 260 and $135 \mathrm{Ma}$, whereas the Chinmen beach monazites (SKM plus KM) reveal three major age peaks at 160,140 and $85 \mathrm{Ma}$ and one minor peak at $215 \mathrm{Ma}$ on the age frequency curve (Fig. 6a and b). Therefore, contribution from the metasedimentary rocks to the
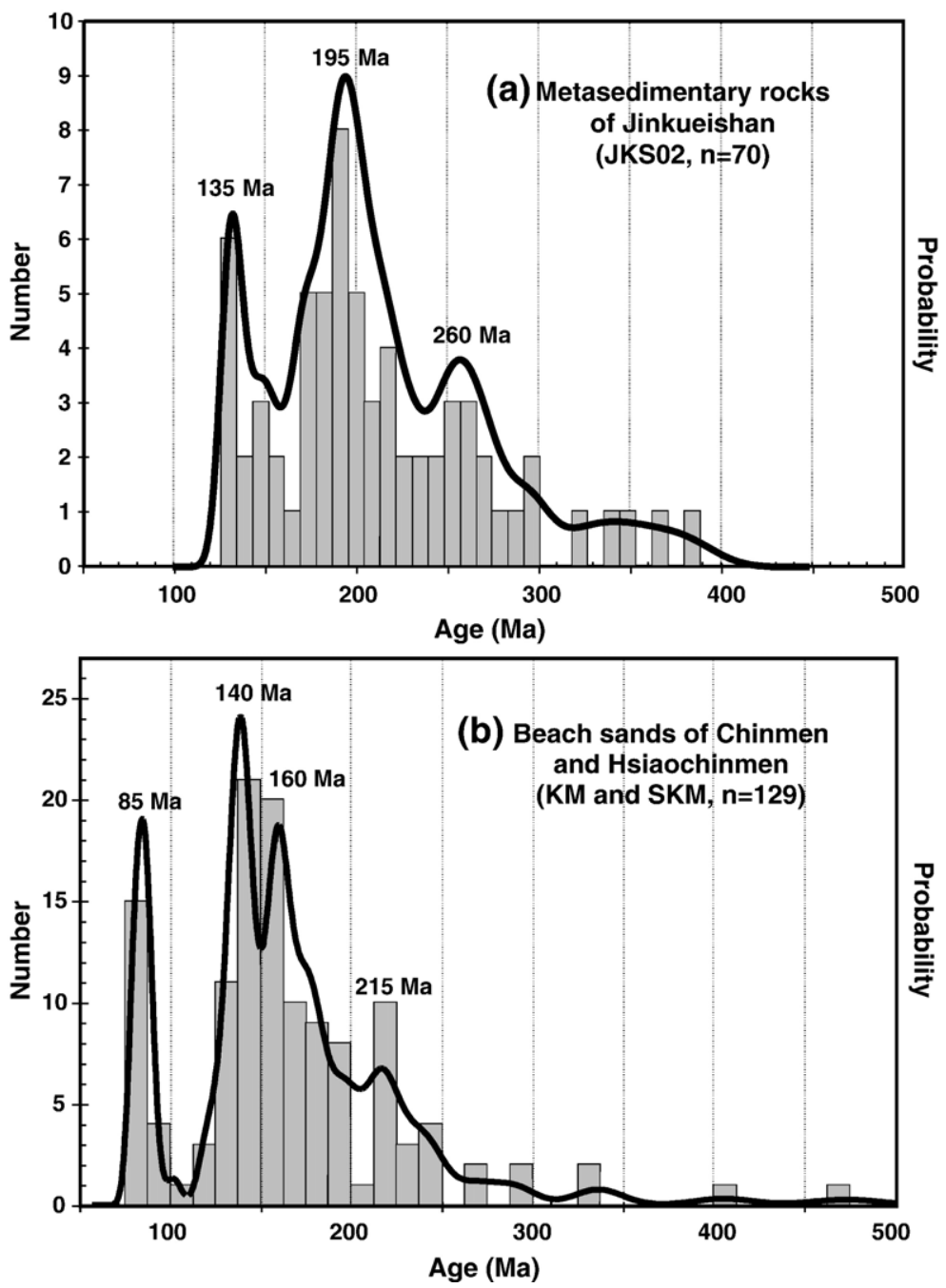

Fig. 6. Age frequency curves of monazites for (a) metasedimentary rocks (represented by the Jinkueishan two-mica schist), and (b) beach sands from Chinmen areas. 
beach sands is minor. They are rather a mixture of the disintegrated Chinmen Formation and the decomposed gneissic bodies. Incision of the Jiulongjiang river system on the EY granitic plutons can certainly bring up eroded materials from pluton sites to deposit as the Chinmen Formation during the Neogene. However, whether there are Indosinian plutons sitting on the pathway of this river remain unsolved.

\subsection{Comparison between NW and SW Taiwan}

Differences for the age population of monazites between the NW (Miaoli-Hsinchu) and SW (ChiayiTainan) Taiwan can somewhat shed the light for sediments deposited during the Neogene and Paleogene. The relative proportion of monazite age population between Phanerozoic and Paleoproterozoic is $52 \%$ vs. $43 \%$ in the north and $61 \%$ vs. $27 \%$ in the south of $\mathrm{W}$ Taiwan, i.e., a less influence of the Paleoproterozoic source as beach sands spread further south (Fig. 7a and b). Reversely, Meso- and Neoproterozoic monazites are more influential in the south (12\%) than the north (3\%). Monazites in the Paleogene strata show an even larger contrast, $83 \%$ vs. 13\%, between Phanerozoic and Paleoproterozoic ages (Fig. 7c). This suggests that the Paleoproterozoic provenance becomes more influential in the later stage of the Cenozoic depositional cycle on this continental margin.

A striking feature for Phanerozoic age populations in the beach sand monazites is that there are strong reflections from relicts of Caledonian, Hercynian and Indosinian events, despite that the SE China coastal area is largely covered by the Yanshanian igneous rocks. In the Paleogene strata (Fig. 7c), the Yanshanian $(34 \%)$ and Indosinian $(38.5 \%)$ predominate over the Hercynian (17.5\%) and Caledonian (10\%). However, Hercynian and Caledonian ages are more widespread in the beach sand monazites, occupying $26 \%$ and $18 \%$ in the north and $36 \%$ and $30 \%$ in the south. Therefore, exposes of the Paleozoic provenances are in concurrence with the Paleoproterozoic effect. Here we also stress the importance of the Indosinian age group within the beach sand monazites: $31 \%$ in the Miaoli-Hsinchu and $16 \%$ in the ChiayiTainan areas.

\subsection{Role of the Wuyishan basement}

Because there are abundant Paleoproterozoic monazites in the W Taiwan sediments, the only well-exposed Precambrian basement in SE China, i.e., the Wuyishan area, must be taken into consideration. The center part of this area, where the Mingjiang River originates (Fig. 1), is a terrain of Paleoproterozoic peraluminous granitoids and amphibolites as revealed from few $\mathrm{U}-\mathrm{Pb}$ zircon ages of amphibolites $(1766 \pm 19 \mathrm{Ma})$, tonalites (1800 $\pm 44 \mathrm{Ma}$ ) and monzogranites ( $1870 \pm 36$ to $1975 \pm 80 \mathrm{Ma}$ ) (Li, 1997; Wang et al., 1998b).

Most recently, Wuyishan is known for the existence of Neoproterozoic rocks surrounding its center in an area greater than those suggested previously (Fig. 1). They are considered as equivalents to the granites with ages of $830-810 \mathrm{Ma}$ that are widespread around the Yangtze craton margin as a consequence of the Late Jinning orogeny (e.g., Wang and Qiao, 1984; Li et al., 2003). For instance, the Mamianshan rhyolite, a member of the bimodal volcanics in the Neoproterozoic sedimentary sequences, exhibits a $\mathrm{U}-\mathrm{Pb}$ zircon age of $818 \pm 9 \mathrm{Ma}$ (Li et al., 2005).

To the southeast of the Wuyishan area, rocks pertaining to the Caledonian thermal events are widespread (FBGMR, 1985). Regional metamorphism up to amphibolite facies and associated plutonism (500$380 \mathrm{Ma}$ ) have been mentioned, however, no precise ages can be referred. Hercynian and Indosinian rocks are seldom recognized in this area and reliable ages so far are only the small Yangfang syenitic body $(242 \pm 4 \mathrm{Ma}$; Wang et al., 2005) and the Dashuang granite (240 $\pm 1 \mathrm{Ma}$; Wang et al., 1998a). Therefore, Wuyishan as a whole is a potential area to supply the Paleo- and Neoproterozoic as well as the Caledonian monazites. Sources for Hercynian and Indosinian monazites are uncertain.

\subsection{Influence of river systems in SE China}

Major rivers in SE China coastal area that have been mentioned as potential contributors for supplying sediments to Taiwan are the Yangtze River (Chen et al., 1990) and the Minjiang River (Bien, 1971; Chen et al., 2000). Drainage systems of rivers in relevance are shown in Fig. 1.

Cored sediments from Yangtze River mouth have been studied for the CHIME monazite age population in different layers (Yokoyama and Zou, 2002). Ages of monazite are marked by the essential Phanerozoic population $(81 \%)$, in which nearly $25 \%$ of these grains are of the Early Miocene. Besides, source of these sediments has changed with time: monazites with ages of 500-350 Ma are dominant in the Pliocene layers and those of $275-100 \mathrm{Ma}$ are more abundant in the Quaternary layers (Fan et al., 2004). Put together all these monazite ages, scarcity of the Paleoproterozoic and the Phanerozoic population for $350-275 \mathrm{Ma}$ in 

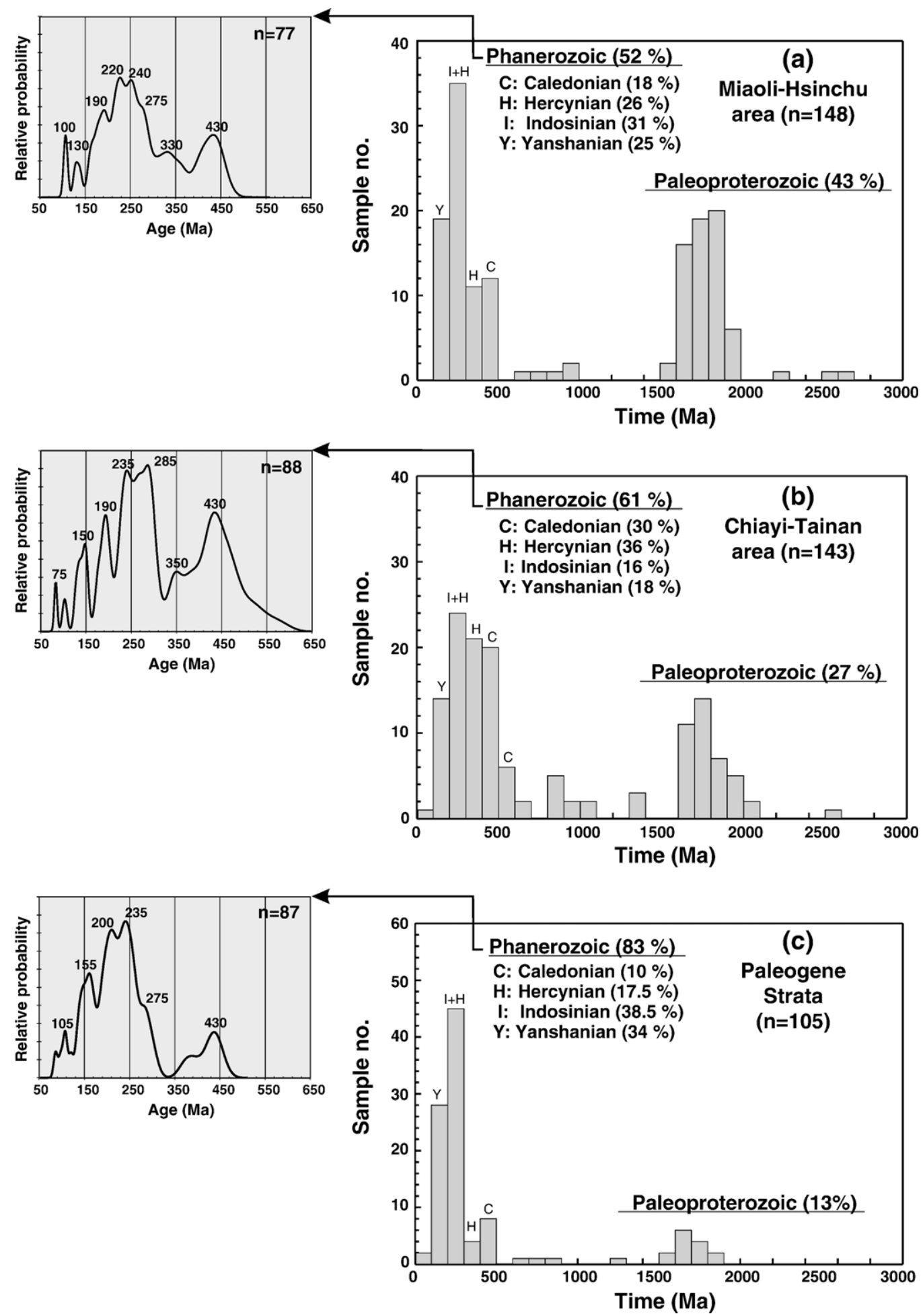

Fig. 7. Histograms of monazite ages of (a) NW and (b) SW Taiwan sediments, and (c) the Paleogene strata in W Taiwan. Age frequency curves for the Phanerozoic population in each area are also depicted. 
sediments from the Yangtze River mouth minimizes its influence on W Taiwan.

The Minjiang system, on the other hand, delivers abundant Paleozoic and Early Mesozoic sediments to the river mouth. When the Phanerozoic total age frequencies of $\mathrm{W}$ Taiwan and Minjiang river mouth monazites are compared, they match within the analytical errors for major peaks in the entire age spectra although the relative proportion of each peak may be different (Fig. 8a and b). The only difference for ages $>180 \mathrm{Ma}$ is the lack of a minor $530 \mathrm{Ma}$ peak in the W Taiwan sediments. The cogenetic relationship can also be supported by the fact that monazites with ages $<180 \mathrm{Ma}$ are relatively in a small proportion for both populations. Short distances of sediment transport suggest that potential sources of Early Phanerozoic monazites are the Wuyishan peripheral beyond the Yanshanian terrain (Fig. 1). Scarcity of Proterozoic monazites in recent sediments of the Minjiang River mouth is puzzling, but may be ascribed to the human construction of some reservoirs and dams in this river (e.g., the Shuikuo Dam in the Minchin County).

\subsection{Supply of $W$ Taiwan sediments through time}

Supply of W Taiwan (including Taiwan Strait) sediments is closely related to the tectonic evolution of the SE China coastal area. In the Early Cretaceous, due to the compressional force caused by the paleoPacific plate subduction, a west-bounding thrust system would cause the CNSZ to expose with the deep-seated gneissic rocks. Exhumation rates were estimated to vary
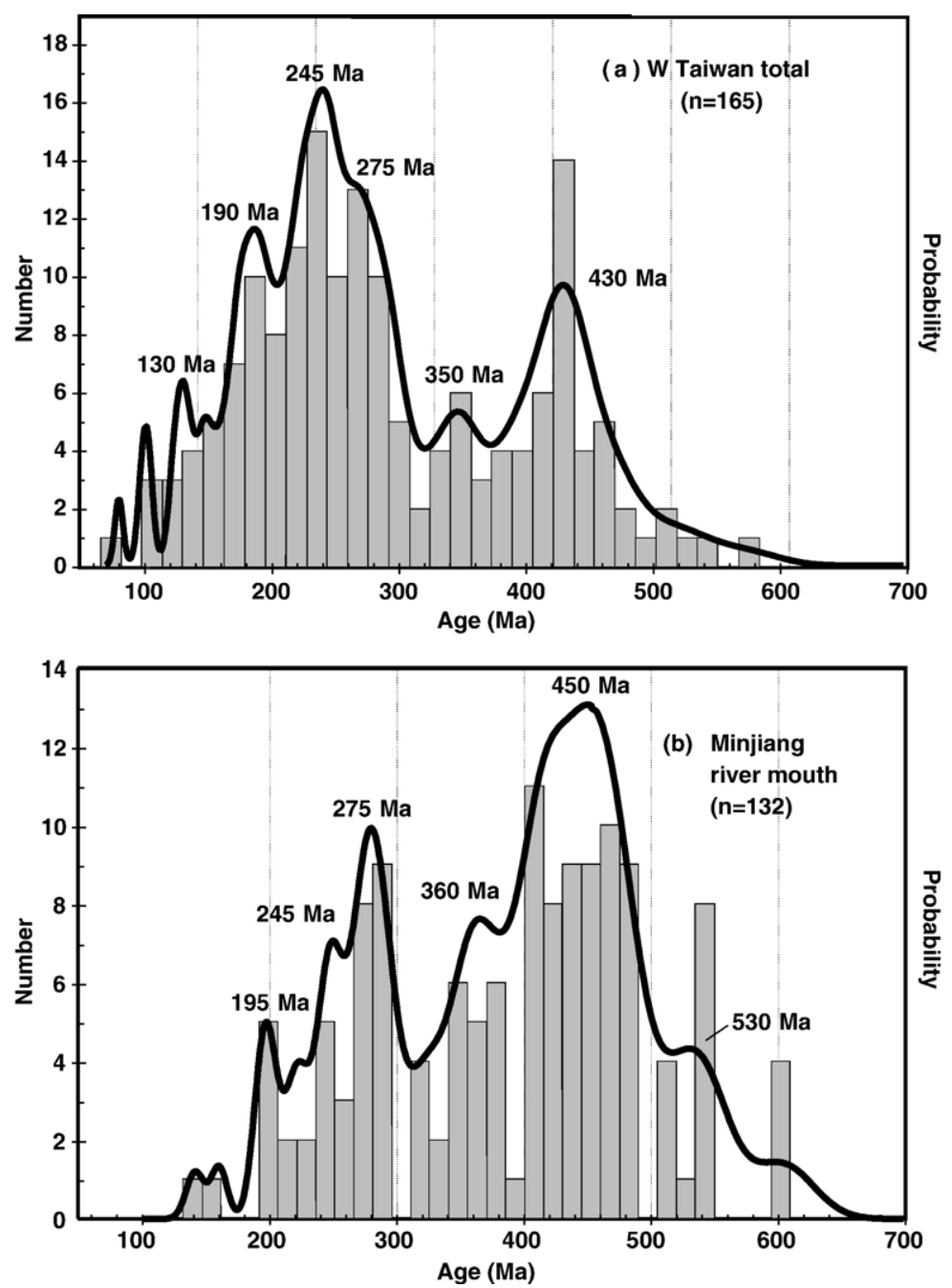

Fig. 8. Age frequency curves of the Phanerozoic monazites for (a) Minjiang River mouth, and (b) W Taiwan sediments. Note that peak ages of two curves are very similar, although relative intensities of the corresponding peaks are different. 
from 1.3 to $0.8 \mathrm{~km} / \mathrm{Myr}$ in different sections of this zone between 130-110 Ma (Chen et al., 2002). With the cover of $>18 \mathrm{~km}$ being deprived, materials eroded from the CNSZ were then transported to build up the Cretaceous sedimentary sequences $(120-100 \mathrm{Ma})$ in the Taiwan Strait (Teng and Lin, 2004).

In the Late Cretaceous, the coastal Fujian turned to an extensional tectonism and became invaded by shallow intrusives and rhyolites (Chen et al., 2004). Therefore, materials delivered to the continental slope were largely the rhyolites from highlands in the LY magmatic belt. Probably until the time when the foreland basin in the continental margin started to form (Lin and Watts, 2002), the CNSZ was eroded with the infilled sediments to redeposit in $\mathrm{W}$ Taiwan. This can explain the phenomenon that only the Paleogene sedimentary sequences in $\mathrm{W}$ Taiwan contain more abundant rhyolite fragments (Chen, 1964) and exhibit higher $\varepsilon \mathrm{Nd}(\mathrm{T})$ values (Lan et al., 2002).

During the Cenozoic, the extensional tectonics continued (Lin and Watts, 2002). In the Paleogene, Minjiang River played a more important role in bringing the Caledonian to Indosinian monazites to W Taiwan. In the Neogene, incision of the Minjiang River had reached a more mature stage to bring greater amounts of eroded materials from the center part of Wuyishan. Thus, Paleoproterozoic monazites can occupy $43 \%$ of the age population of the NW Taiwan sediments (Fig. 7a).

\section{Inferred Cathaysia crust in the SE China coastal area}

\subsection{Precambrian crust}

Main stages for the Precambrian accretion of the Cathaysia crust have been suggested to be $2.5,2.1,1.8$, $1.4-1.2$ and $\sim 1.0 \mathrm{Ga}$ as deduced from zircon inheritance ages of the Phanerozoic granitoids in SE China and NE Taiwan (Jahn et al., 1986; Li et al., 1992; Yui et al., 1996). Basements exposed in SE China that can support these events are mainly the highly metamorphosed Paleoproterozoic and less extensively metamorphosed Neoproterozoic rocks (Shen and Lin, 2002). Combining all these data, five Precambrian stages of crustal growth (I to V) in the Cathaysia Block, namely, $\sim 2.5,2.1,1.9-1.7,1.4-1.2$ and $1.1-0.8 \mathrm{Ga}$, are suggested (Fig. 9a). Such age distributions are similar to those reported for sediments of major rivers in the Indochina continent (Bodet and Scharer, 2000). In this study we found that monazite ages of W Taiwan sediments generally match these five characteristic stages (Table 1).

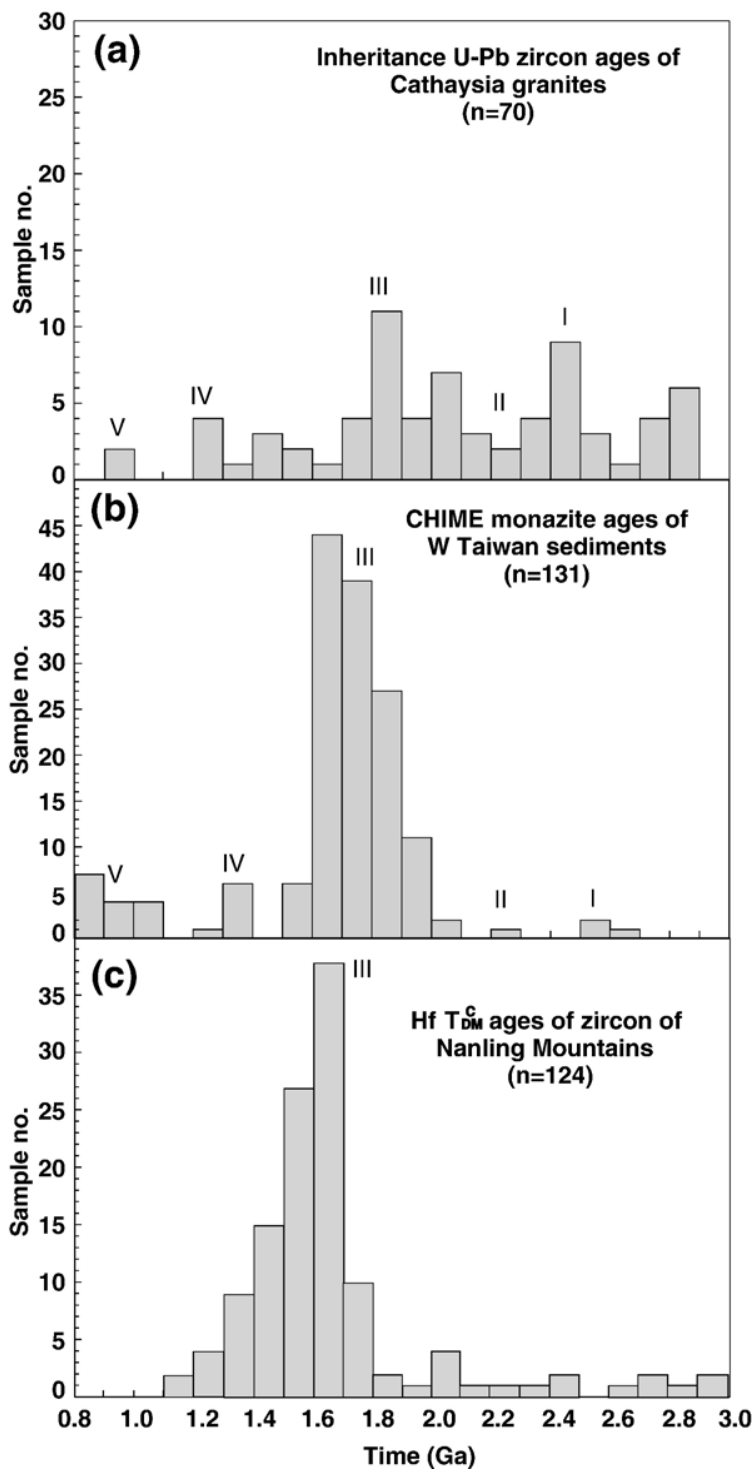

Fig. 9. Precambrian age histograms for (a) zircon inheritance ages of granites in the Cathaysia Block (Shen and Lin, 2002; Yui et al., 1996; Jahn et al., 1986), (b) monazite ages of W Taiwan sediments (this study), and (c) mean $\mathrm{Hf}$ isotope model ages ( $\mathrm{Hf} \mathrm{T}_{\mathrm{DM}}^{\mathrm{C}}$ ) of zircons of the Nanling Mountains, S China (Xu et al., 2005).

Since early accretions in the SE China continent reflected by the inherited zircons are multi-stage and developed from the Late Archean to Neoproterozoic, the W Taiwan monazites dominated in the stage III (Fig. 9b) most probably indicate derivatives of a single source on this continent or the restriction of monazites in specific rock types. Although zircon inheritance ages of 1.9$1.7 \mathrm{Ga}$ are commonly obtained from Yanshanian granitoids in SE China, Chinmen and NE Taiwan (Table 1), our data of Chinmen samples indicate that the Paleoproterozoic ages are, in principle, unlikely 
Table 1

Precambrian age records (Ga) in SE China, Indochina, and Taiwan

\begin{tabular}{|c|c|c|c|c|c|c|}
\hline Age stage & I & II & III & IV & $\mathrm{V}$ & References \\
\hline \multicolumn{7}{|c|}{ 1. $U-P b$ zircon inheritance ages of granitoids } \\
\hline Cathaysia granites, & 2.5 & & 1.8 & $1.4-1.2$ & & Li et al. (1992) \\
\hline SE China* & $2.5-2.4$ & & $1.9-1.7$ & & $1.1-0.9$ & Shen and Lin (2002) \\
\hline Chinmen granites and gneiss & & & $1.8-1.7$ & & & Yui et al. (1996) \\
\hline NE Taiwan granites & & & 1.7 & & 1.0 & Jahn et al. (1986) \\
\hline and gneisses & & 2.1 & & & & Yui et al. (1996) \\
\hline \multicolumn{7}{|l|}{ 2. $U-P b$ zircon ages } \\
\hline Wuyishan & & & $1.8-1.7$ & & & Li (1997); \\
\hline metamorphic rocks & & & & & 0.8 & Li et al. (2005) \\
\hline Indochina river sediments & 2.5 & 2.3 & 1.9 & 1.1 & 0.8 & Bodet and Scharer (2000) \\
\hline \multicolumn{7}{|l|}{ 3. CHIME monazite ages } \\
\hline Yangtze river mouth sediments & & & $1.9-1.8$ & & 0.8 & Yokoyama and Zou (2002) \\
\hline Minjiang river mouth sediments & & & 1.7 & & 0.8 & This study \\
\hline W Taiwan sediments & $2.6-2.5$ & 2.3 & $1.8-1.6$ & 1.3 & $1.0-0.8$ & This study \\
\hline
\end{tabular}

*The inheritance age of $2.8 \mathrm{Ga}$ for Cathaysia granites reported by Shen and Lin (2002) is not included.

inherited from the rounded monazite nuclei being incorporated in these granitoids.

Most recently, Xu et al. (2005) reported the mean Hf isotope model ages ( $\mathrm{Hf} \mathrm{T}_{\mathrm{DM}}^{\mathrm{C}}$ ) of zircons of the Nanling Mountains in the Cathaysia interior, indicating the mono-peak age of 1.8-1.6 Ga (Fig. 9c). Therefore, the Paleoproterozoic event is a common feature for both the Cathaysia interior and coastal area. In addition, based on the presence of Archean zircons (2.7-2.5 Ga) in the Mesoproterozoic basement $(\sim 1.4 \mathrm{Ga})$, they envisaged that the Cathaysia Block may include Archean microcontinent fragment. Due to very small number of Archean monazite ages in $\mathrm{W}$ Taiwan, the proposition that the eastern part of Cathaysia $(1.9-1.7 \mathrm{Ga})$ had accreted along the $\sim 2.5 \mathrm{Ga}$ Archean nucleus ( $\mathrm{Zhu}$, 1999; Xu et al., 2005) needs further verifications.

\subsection{Phanerozoic crust}

Some Phanerozoic thermal events in the SE China can be reflected by the monazite age frequency curves of the W Taiwan and Minjiang samples (Fig. 8a and b). Particularly, peak ages corresponding to the Caledonian (450-430 Ma), Early and Late Hercynian (360-350 and $\sim 275 \mathrm{Ma}$ ), and Indosinian $(\sim 245 \mathrm{Ma})$ orogenies are noted. This infers the existence or concealing of such crusts in the SE China coastal area although many local geologists advocate that there are no Hercynian granitoids in S China (e.g., Xu et al., 2005). It is also noted that the Indosinian peak age here is slightly older than that in Chinmen $(\sim 220 \mathrm{Ma})$, indicating two stages of Indosinian thermal events in the SE China coastal area and the CNSZ. The Cambrian age group of 540-510 Ma appeared in sediments of the Minjiang river mouth and SW Taiwan is similar to those obtained from sediments in the Permian to Early Mesozoic Shiwandashan Basin, S China (X.H. Li, 2005; personal communication). However, like the case of the Hercynian ages, no any igneous/metamorphic event and/or provenances in $\mathrm{S}$ China are known.

The Yanshanian thermal activities seem to have reactivated cyclically. Ages of the Early Jurassic monazite are peaked at $195 \mathrm{Ma}$ in Minjiang and $190 \mathrm{Ma}$ in W Taiwan sediments (Fig. 8). They are similar to the highest age peak for the metasedimentary rocks in Chinmen (Fig. 6a), indicating the common existence of 195-190 Ma rocks in the inner Fujian. This probably marks the initiation of the EY orogeny in the SE China coastal area. Late Jurassic thermal activities at $\sim 160 \mathrm{Ma}$ that prevailed in the Cathaysia interior (Chen and Jahn, 1998) show a strong sign in Chinmen (Fig. 6b) but leave insignificant traces in $\mathrm{W}$ Taiwan (Fig. 7). We suggest that the shear stress in the CNSZ had caused remelting of the pre-existing igneous rocks $(\sim 220 \mathrm{Ma})$ and formed the $\sim 140$ Ma gneissic rocks in the beginning of the LY syn-orogenic stage. The 120-80 Ma intrusive and volcanic rocks in the SE China coastal area were mainly controlled by the subduction-related magmatism in the LY post- and an-orogenic stages, in which only the 90-80 Ma rhyolites involve large degree of crust melting to account for the monazite ages of this group (Fig. 6b).

\section{Conclusions}

Beach sands of the W Taiwan contain significant populations of Paleoproterozoic $(\sim 1.8 \mathrm{Ga})$ monazites. 
Sediments from the Minjiang River in N Fujian, China, are considered the most likely source of these monazites through the transport of sediments from the Wuyishan area. Because monazite occurrence in igneous and metamorphic rocks is restricted to peraluminous bulk compositions, contribution from the metaluminous Mesoproterozoic rocks like the Nanling Mountains $(\sim 1.3 \mathrm{Ga}, \mathrm{Xu}$ et al., 2005$)$ is uncertain. However, coastal area of the Cathaysia Block has been repeatedly overprinted by the Caledonian, Hercynian and Indosinian ( \pm Early Yanshanian) thermal events before being covered by the Late Yanshanian intrusive and volcanic rocks.

The provenance of some Phanerozoic monazites, which may be related to orogenies in SE China, is still unknown. These include: (1) the classical Caledonian orogeny has been widely accepted for the early Paleozoic thermal pulses, particularly in Ordovician and Silurian time. Here we found one additional thermal record in the Cambrian, at 540-510Ma. (2) Traditionally, Hercynian orogeny includes the Late Paleozoic orogenic era extending through the Carboniferous and Permian. Our data suggest that a large number of Hercynian monazites exist in the sediments of W Taiwan and the Minjiang River, peaking at 360$350 \mathrm{Ma}$ (Early Carboniferous) and $\sim 275 \mathrm{Ma}$ (Early Permian), respectively.

The Indosinian orogeny is a well-known thermal event responsible for the generation of the Darongshan S-type granitoids in southern China. Our data suggest that Indosinian activities could be equally important in SE China coastal area and there might be two stages in this orogenic event, i.e., $\sim 245$ and $\sim 220$ Ma. The latter group is particularly obvious in the cores of monazite from Chinmen. The Early Yanshanian movement $(\sim 160 \mathrm{Ma})$ that prevailed in the Cathaysia interior does not show a strong sign to extend to the coastal area. Severe Late Yanshanian overprints of the Indosinian ( \pm Early Yanshanian) crusts, mainly occurred at $\sim 140 \mathrm{Ma}$, are clearly represented in gneissic rocks of the CNSZ and are regarded as the onset of the Late Yanshanian magmatism.

\section{Acknowledgements}

The authors are indebted to Profs. L. P. Tan and Y. Wang and Mr. K. L. Soong for supplying monazite samples, and to Mr. R. S. Chen (Fujian) who helped sampling on the Minjiang River mouth. We benefited from discussions with Profs. L. S. Teng and W. S. Chen (Taipei), K. Suzuki (Nagoya) and X. H. Li (Guangzhou). Comments by Dr. R. Rudnick (the Editor), Dr. I.
Braun and one anonymous reviewer help to improve the manuscript greatly. This work is supported by research grants from the National Science Council (NSC-82(83)0202-M002-108(91)/Chen). [RR]

\section{Appendix A. Supplementary data}

Supplementary data associated with this article can be found, in the online version, at doi:10.1016/j. chemgeo.2006.01.023.

\section{References}

Bien, E.M., 1971. The Middle Miocene Talu Sandstone reservoir of northwest Taiwan. Pet. Geol. Taiwan 9, 1-18.

Bingen, B., Demaiffe, D., Hertogen, J., 1996. Redistribution of rare earth elements, thorium, and uranium over accessory minerals in the course of amphibolite to granulite facies metamorphism: the role of apatite and monazite in orthogneisses from southwestern Norway. Geochim. Cosmochim. Acta 60, 1341-1354.

Bodet, F., Scharer, R., 2000. Evolution of the SE-Asian continent from $\mathrm{U}-\mathrm{Pb}$ and $\mathrm{Hf}$ isotopes in single grains of zircon and baddeleyite from large rivers. Geochim. Cosmochim. Acta 64, 2067-2091.

Braun, I., Montel, J.-M., Nicollet, C., 1998. Electron microprobe dating of monazites from high-grade gneisses and pegmatites of the Kerala Khondalite Belt, southern India. Chem. Geol. 146, $65-85$.

Chen, P.Y., 1964. Rhyolite pebbles in the white sandstone of the Wuchihshan Formation of Taiwan. Proc. Geol. Soc. China 6, 34-40.

Chen, J., Jahn, B.-M., 1998. Crustal evolution of southeastern China: $\mathrm{Nd}$ and $\mathrm{Sr}$ isotopic evidence. Tectonophysics 284, 101-133.

Chen, C.-H., Tung, T.C., 1984. On-line data reduction for electron microprobe analysis. Acta Geol. Taiwan 22, 196-200.

Chen, C.H., Jahn, B.M., Lee, T., Chen, C.H., Cornichet, J., 1990. Sm$\mathrm{Nd}$ isotopic geochemistry of sediments from Taiwan and implications for the tectonic evolution of southeast China. Chem. Geol. 88, 317-332.

Chen, W.S., Erh, C.H., Chen, M.M., Yang, C.C., Chang, I.S., Liu, T. K., Horng, C.S., Sher, K.S., Yeh, M.G., Wu, J.C., Ko, C.T, Lin, C. C., Huang, N.W., 2000. The evolution of foreland basins in the western Taiwan: evidence from the Plio-Pleistocene sequences. Bull. Cent. Geol. Surv. 13, 137-156 (in Chinese with English abstract).

Chen, W.S., Yang, H.C., Wang, X., Huang, H., 2002. Tectonic setting and exhumation history of the Pingtan-Dongshan metamorphic belt along the coastal area, Fujian Province, southeast China. J. Asian Earth Sci. 20, 829-840.

Chen, C.-H., Lin, W., Lan, C.Y., Lee, C.Y., 2004. Geochemical and $\mathrm{Sr}, \mathrm{Nd}$ isotopic characteristics and tectonic implications for three stages of igneous rock in the Late Yanshanian (Cretaceous) orogeny, SE China. Trans. Royal Soc. Edinburgh: Earth Sci. 95, 237-248.

Cherniak, D.J., Watson, E.B., Grove, M., Harrison, T.M., 2004. Pb diffusion in monazite: a combined RBS/SIMS study. Geochim. Cosmochim. Acta 68, 829-840. 
Cocherie, A., Albarede, F., 2001. An improved U-Th- $\mathrm{Pb}$ age calculation for electron microprobe dating of monazite. Geochim. Cosmochim. Acta 65, 4509-4522.

Cocherie, A., Legendre, O., Peucat, J.J., Kouamelan, A.N., 1998. Geochronology of polygenetic monazites constrained by in situ electron microprobe Th-U-total lead determination: implications for lead behaviour in monazite. Geochim. Cosmochim Acta 62, 2475-2497.

Cocherie, A., Be Mezeme, E., Legendre, O., Fanning, C.M., Faure, M., Rossi, P., 2005. Electron-microprobe dating as a tool for determining the closure of $\mathrm{Th}-\mathrm{U}-\mathrm{Pb}$ systems in migmatitic monazites. Am. Mineral. 90, 607-618.

Crowley, J.L., Ghent, E.D., 1999. An electron microprobe study of the $\mathrm{U}-\mathrm{Th}-\mathrm{Pb}$ systematics of metamorphosed monazite: the role of $\mathrm{Pb}$ diffusion versus overgrowth and recrystallization. Chem. Geol. $157,285-302$.

Deng, X., Chen, Z., Li, X., Liu, D., 2004. SHRIMP U-Pb zircon dating of the Darongshan-Shiwandashan granitoid belt in southeastern Guanxi, China. Geol. Rev. 50, 426-432 (in Chinese with English abstract).

Dunning, G.R., Macdonald, A.S., Barr, S.M., 1995. Zircon and monazite $\mathrm{U}-\mathrm{Pb}$ dating of the Doi Inthanon core complex, northern Thailand: implications for extension within the Indosinian Orogen. Tectonophysics 251, 197-213.

Fan, D., Li, C., Yokoyama, K., Zhou, B., Li, B., Wang, C., Yang, S., Deng, B., Wu, G., 2004. Monazite age spectra of the Late Cenozoic strata in Yangtze Delta and the timing of breakthrough of the Yangtze River. Sci. China (Series D) 34, 1015-1022 (in Chinese with English abstract).

FBGMR (Fujian Bureau of Geology and Mineral Resources), 1985. The Geology of Fujian. Geology Press, Beijing. 617 pp (in Chinese with English abstract).

Jahn, B.-M., Chen, P.Y., Yen, T.P., 1976. Rb-Sr ages of granitic rocks in southeastern China and their tectonic significance. Bull. Geol. Soc. Am. 87, 763-776.

Jahn, B.-M., Martineau, F., Peucat, J.J., Cornichet, J., 1986. Geochronology of the Tananao Schist Complex, Taiwan and its regional tectonic significance. Tectonophysics 125, 103-124.

Kato, T., Suzuki, K., Adachi, M., 1999. The computer program for the CHIME age calculation. J. Earth Planet. Sci. Nagoya Univ. 46, $49-56$.

Lan, C.Y., Lee, C.S., Shen, J.J., Lu, C.Y., Mertzman, S.A., Wu, T.W., 2002. Nd-Sr isotopic composition and geochemistry of sediments from Taiwan and their implications. West. Pac. Earth Sci. 2, 205-222.

Li, X.H., 1997. Timing of the Cathaysia Block initiation: constraints from SHRIMP U-Pb zircon geochronology. Episodes 20 (3), $188-192$.

Li, X., Zhao, Z., Gui, X., Yu, J., 1992. Sm-Nd and zircon U-Pb isotopic constraints on the age of formation of the Precambrian crust in southeast China. Chin. J. Geochem. 11, 111-120.

Li, X.H., Li, Z.H., Ge, W., Zhou, H., Li, W., Liu, Y., Wingate, M.T. D., 2003. Neoproterozoic granitoids in South China: crustal melting above a mantle plume at ca. 825 Ma? Precam. Res. 122, 45-83.

Li, W.X., Li, X.H., Li, Z.X., 2005. Neoproterozoic bimodal magmatism in the Cathaysia block of South China and its tectonic significance. Precam. Res. 136, 51-66.

Lin, A.T., Watts, A.B., 2002. Origin of the west Taiwan basin by orogenic loading and flexure of a rifted continental margin. J. Geophys. Res. 107 (B9), 2185. doi:10.1029/2001JB0000669.
Ludwig, K.R., 2003. ISOPLOT 3.00: A Geochronological Toolkit for Microsoft Excel. Berkeley Geochronology Center Special Publication, Berkeley, California.

Matzko, J.J., Overstreet, W.C., 1977. Black monazite from Taiwan. Proc. Geol. Soc. China 20, 16-35.

Montel, J.-M., Foret, S., Veschambre, M., Nicollet, C., Provost, A., 1996. Electron microprobe dating of monazite. Chem. Geol. 131, 37-53.

Montel, J.-M., Kornprobst, J., Vielzeuf, D., 2000. Preservation of old $\mathrm{U}-\mathrm{Th}-\mathrm{Pb}$ ages in shielded monazite: example from the Beni Bousera Hercynian kinzigites (Morocco). J. Metamorph. Geol. 18, 335-342.

Overstreet, W.C., 1971. Monazite in Taiwan. U. S. Geol. Surv. (Open File Report, $80 \mathrm{pp}$ ).

Parrish, R.R., 1990. U-Pb dating of monazite and its application to geological problem. Can. J. Earth Sci. 27, 1431-1450.

Pyle, J.M., Spear, F.S., Wark, D.A., Daniel, C.G., Storm, L.C., 2005. Contributions to precision and accuracy of monazite microprobe ages. Am. Miner. 90, 547-577.

Rhede, D., Wendt, I., Forster, H.-J., 1996. A three-dimensional method for calculating independent chemical $\mathrm{U} / \mathrm{Pb}$ - and $\mathrm{Th} / \mathrm{Pb}$-ages of accessory minerals. Chem. Geol. 130, 247-253.

Seydoux-Guillaume, A.M., Paquette, J.-L., Wiedenbeck, M., Montel, J.-M., Heinrich, W., 2002. Experimental resetting of the U-Th-Pb systems in monazite. Chem. Geol. 191, 165-181.

Shen, W., Lin, H., 2002. Isotope studies of basement metamorphic, granitic and volcanic rocks in SE China and its crust evolution. In: Wang, D., Zhou, X. (Eds.), Genesis of Late Mesozoic Granitic Volcanic-Plutonic Complexes in SE China and Crustal Evolution. Science Press, Beijing, pp. 230-272 (in Chinese).

Suzuki, K., Adachi, M., 1994. Middle Precambrian detrital monazite and zircon from the Hida gneiss on Oki-Dogo Island, Japan: their origin and implications for the correlation of basement gneiss of southwest Japan and Korea. Tectonophysics 235, 277-292.

Suzuki, K., Adachi, M., 1998. Denudation history of the high T/P Ryoke metamorphic belt, southeast Japan: constraints from CHIME monazite ages of gneisses and granitoids. J. Metamorph. Geol. 16, 23-37.

Suzuki, K., Adachi, M., Nureki, T., 1996. CHIME age dating of monazites from metamorphic rocks and granitic rocks of the Ryoke belt in the Iwakuni area, southwest Japan. Isl. Arc 5, 43-55.

Teng, L.S., Lin, A.T., 2004. Cenozoic tectonics of the China continental margin, insights from Taiwan. In: Malpas, J., et al. (Ed.), Aspect of the Tectonic Evolution of China. Geol. Soc. London Special Publication, vol. 226, pp. 313-332.

Tsuboi, M., Suzuki, K., 2003. Heterogeneity of initial ${ }^{87} \mathrm{Sr} /{ }^{86} \mathrm{Sr}$ ratios within a single pluton: evidence from apatite strontium isotopic study. Chem. Geol. 199, 189-197.

Wang, H., Qiao, X., 1984. Proterozoic stratigraphy and tectonic framework of China. Geol. Mag. 121, 599-614.

Wang, Y., Zhao, Z., Bao, Z., Li, X., 1998a. Geochemistry of granitoid rocks and crustal evolution from Zhejiang province, China-I. Phanerozoic granitoid rocks. Chin. J. Geochem. 17, 201-212.

Wang, Y., Zhao, Z., Bao, Z., Li, X., 1998b. Geochemistry of granitoid rocks and crustal evolution from Zhejiang province, China. Proterozoic granitoid rocks. Chin. J. Geochem. 17, 291-302.

Wang, Q., Li, J.W., Jian, P., Zhao, Z.H., Xiong, X.L., Bao, Z.W., $\mathrm{Xu}$, J.F., Li, C.F., Ma, J.L., 2005. Alkaline syenites in eastern Cathaysia (South China): link to Permian-Triassic transtension. Earth Planet. Sci. Lett. 230, 339-354. 
Williams, M.L., Jercinovic, M.J., 2002. Microprobe monazite geochronology: putting absolute time into microstructural analysis. J. Struct. Geol. 24, 1013-1028.

Xu, X., O’Reilly, S.Y., Griffin, W.L., Deng, P., Pearson, N.J., 2005. Relict Proterozoic basement in the Nanling Mountains (SE China) and its tectonothermal overprinting. Tectonics 24, TC2003. doi:10.1029/2004TC001652.

Yang, H.C., Chen, W.S., Lo, C.H., Chen, C.H., Huang, H., Wang, H., Wang Lee, C., 1997. ${ }^{40} \mathrm{Ar} /{ }^{39} \mathrm{Ar}$ thermochronology of granitoids from the Pingtan-Dongshan Metamorphic Belt and its tectonic implication. J. Geol. Soc. China 40, 559-585.
Yokoyama, K., Zou, B., 2002. Preliminary study of ages of monazites in sands from the Yangtze River. Nat. Sci. Mus. Monogr. 22, 83-88.

Yui, T.-F., Heaman, L., Lan, C.-Y., 1996. U-Pb and Sr isotopic studies on granitoids from Taiwan and Chinmen-Lieyu and tectonic implications. Tectonophysics 263, 61-76.

Zhu, B.Q., 1999. Discussion on geochemical division and affinity of East Asia blocks: implications for tectonic framework. In: Metcalfe, I. (Ed.), Gondwana Dispersion and Asian Accretion. Balkema, Rotterdam, pp. 211-227. 